IZA DP No. 6309

Vocational High School or Vocational College?

Comparing the Transitions from School to Work

Cristina Lopez-Mayan

Catia Nicodemo

January 2012 


\title{
Vocational High School or Vocational College? Comparing the Transitions from School to Work
}

\author{
Cristina Lopez-Mayan \\ Universitat Autònoma de Barcelona \\ Catia Nicodemo \\ Universitat Autònoma de Barcelona \\ and IZA
}

Discussion Paper No. 6309
January 2012

IZA

P.O. Box 7240

53072 Bonn

Germany

Phone: +49-228-3894-0

Fax: +49-228-3894-180

E-mail: iza@iza.org

\begin{abstract}
Any opinions expressed here are those of the author(s) and not those of IZA. Research published in this series may include views on policy, but the institute itself takes no institutional policy positions.

The Institute for the Study of Labor (IZA) in Bonn is a local and virtual international research center and a place of communication between science, politics and business. IZA is an independent nonprofit organization supported by Deutsche Post Foundation. The center is associated with the University of Bonn and offers a stimulating research environment through its international network, workshops and conferences, data service, project support, research visits and doctoral program. IZA engages in (i) original and internationally competitive research in all fields of labor economics, (ii) development of policy concepts, and (iii) dissemination of research results and concepts to the interested public.
\end{abstract}

IZA Discussion Papers often represent preliminary work and are circulated to encourage discussion. Citation of such a paper should account for its provisional character. A revised version may be available directly from the author. 


\section{ABSTRACT}

\section{Vocational High School or Vocational College? Comparing the Transitions from School to Work}

Using a specific micro-dataset with information on working histories, we analyse the labour market entry of Spanish youths who have completed vocational education. According to the education system, young people can enter the labour market with vocational high school (upper secondary education) or with vocational college (tertiary education). Both present a period of workplace training, although, as they belong two distinct schooling levels, they have different entry requirements. Those who complete vocational college has spent more years in education and we would expect more success in finding a first job. Surprisingly, results do not confirm this hypothesis. We do not find important differences in the estimates of the determinants of transitions across types of vocational education. Apprenticeship has a very important role on increasing the hazard rate to employment and this result holds after controlling for unobserved heterogeneity and previous labour experience.

JEL Classification: J13, J24, I20

Keywords: duration models, vocational education, labour market entry, apprenticeship

Corresponding author:

Cristina Lopez-Mayan

Universitat Autònoma de Barcelona

Facultat d'Economia i Empresa

Edifici B, Campus de Bellaterra

08193 Bellaterra, Cerdanyola del Valles, Barcelona

Spain

E-mail: cristina.lopez.mayan@uab.es

\footnotetext{
* We are very grateful to the seminar participants at UAB, the AIEL Conference in Milan and the SAEe in Malaga for useful comments. Financial support from the Fundación Ramón Areces (Ayuda Investigación 2010) is gratefully acknowledged. All errors are our own responsibility.
} 


\section{Introduction}

The transition from initial education to the labour market is a very important event in the life of young people. In general, they leave education and enter the labour market having a lack of work experience. In consequence, this transition is an uncertain process and its success will depend greatly on the labour market context and on the type of education pathway (general, school-based vocational or apprenticeship) followed by a person (OECD, 2000). In addition, from an individual perspective, the transition from education to work is also relevant because bad outcomes in early working life can have negative consequences on later outcomes (see, for instance, Heckman and Borjas, 1980; Gregg, 2001; or Stewart, 2007). In this context, a better understanding of the school-to-work transitions is a vital aspect of the educational policy and an important issue to be analysed in all countries ${ }^{1}$. Regarding this, school-based vocational and apprenticeship paths improve connections with the labour market by providing an initial work experience. This experience combined with education can enhance transitions in several ways: it aids the matching between employers and young people, reducing unemployment or inactivity spells; it develops workrelated knowledge and skills; and it makes learning more applied and relevant (OECD, 2000).

In this paper, we analyse the school-to-work transitions in Spain for individuals who have completed vocational education. The Spanish education system presents general and vocational paths. Vocational education is school-based, oriented to provide a specific qualification to access the labour market. This path makes less sharp the transition between the classroom and the labour market through school-organised workplace experience programs. Vocational paths are available at upper secondary (vocational high school) and tertiary education (vocational college). Both present a period of apprenticeship, although, as they belong to different schooling levels, they have also different entry requirements: enrollment in vocational high school requires the compulsory schooling diploma while in vocational college the certificate corresponding to the general upper secondary track is needed. This implies that individuals with vocational college have more years of education than individuals with vocational high school. In Spain, vocational education is not the option followed by most young people. As we show in Section 2, around $20 \%$ of people aged 20-29 years old have completed vocational studies over 2001-2007 while around 43\% have finished the general track of upper secondary schooling or university.

Given this framework, the objective of this paper is to explore the determinants of the transitions from vocational school to work and to analyse whether exist differences between the two vocational levels. As vocational college entails more years of education, we would expect that the entry in the labour market is more successful. In our analysis, we study transitions by looking at the number of months to find a first job and a first "significant" job (a job which lasts at least six consecutive months).

\footnotetext{
${ }^{1}$ See Ryan (2001) for a cross-national analysis of school-to-work transitions.
} 
Several studies explore the school-to-work transitions in Spain². Dolado et al. (2000) find that individuals with a university degree have higher employment rates than individuals with upper secondary education. Bover and Gomez (2004) show that university education increases the probability of exit to a permanent job while it reduces the probability of getting a temporary one. Blazquez-Cuesta and Garcia-Perez (2007) put the attention on the unemployment and employment hazard rates of youths and the effect of decentralization of education expenditure. They find that public expenditure increases the probability to find a job and this effect is higher in regions where spending has not been decentralized. Albert et al. (2008) look at the duration to find the first significant job by using the ad hoc module of the Labour Force Survey in 2000. They find that women have poorer labour market outcomes than men but this is related to differences in the fields of study. However, we could not find papers that analyse transitions from vocational school to labour market in Spain. Therefore, our main contribution to the literature is to shed light on this aspect and, specifically, on the role of apprenticeship on smoothing those transitions. We consider that this is a very important issue from a policy perspective, specially today, when young people have difficulties to enter the labour market due to the strong recession.

For our purpose, we use a unique micro-dataset on schooling and labour histories elaborated by the Spanish Statistics Institute in 2005 (Survey on Education and Labour Market Transitions). It contains representative samples of individuals who completed vocational high school or vocational college in the school year 2000/2001. This dataset is very adequate for our study for two main reasons. First, people are observed at the begining of their labour careers, after completing the corresponding level of vocational education. Second, all sampled individuals have finished vocational education in the same year (2001). Thus, independently of the vocational level completed, they face the same economic conditions when they start searching for a job.

Applying duration techniques, our results show that the patterns of the empirical hazards to the first (significant or not) job are very similar in the two groups of vocational education. We neither find important differences in the estimates of the determinants of duration (gender, apprenticeship, type of school, parents' education,...) between types of vocational levels. Nevertheless, both in vocational high school and vocational college, we obtain that apprenticeship has a very important role on increasing the hazard rate to employment and this result holds after controlling for unobserved heterogeneity and previous labour experience.

The rest of the paper is organized as follows. Next Section provides an overview of the Spanish education system. Section 3 describes the dataset we use. Section 4 presents the duration analysis and Section 5 shows the results. Finally, Section 6 and Section 7 discusses and concludes, respectively.

\footnotetext{
${ }^{2}$ For other European countries, see, for instance, Parey (2009) for Germany or Bertschy et al. (2008) for Switzerland.
} 


\section{Spanish education system}

In Spain, compulsory schooling covers ten years, up to the age of sixteen. Then, young people can proceed to post-compulsory secondary education (high school) or they can enter the labour market (see Figure 1). In the high school level, an individual can choose between attending academic high school and vocational high school. After completing upper secondary education, a person can decide to attend university or vocational college (tertiary education). Access to university requires the academic high school diploma and to pass a general (not university-specific) test. Access to vocational college is direct from the academic track but not from the vocational track. From the latter, it is required to pass an admission test. The schooling system allows to attend academic high school after completing the vocational track and it also permits to attend university after graduating from vocational college.

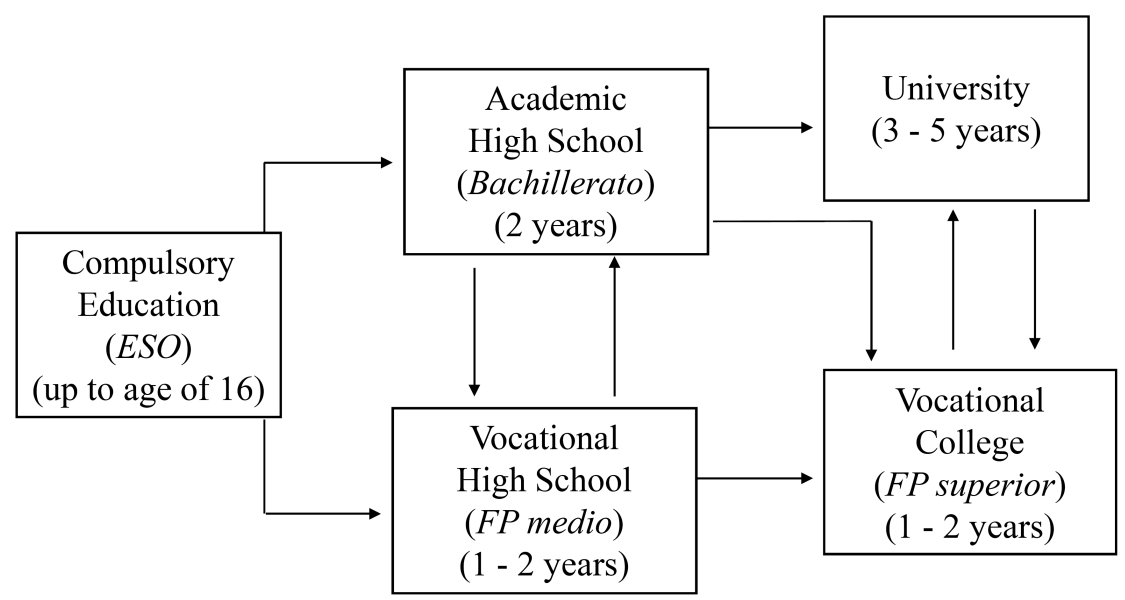

Figure 1: Schooling levels in post-compulsory education

Education received both in vocational high school and vocational college is a schooling-based training with apprenticeship in firms. This education is oriented to give individuals a specific qualification to enter the labour market. In particular, the fields of programs offered include, for example, manufacturing; health; building; clerical support; agriculture, forestry and fishery;... The duration of the programs ranges between one and two years and apprenticeship in firms supposes up to a twenty-five percent of that time. Apprenticeship is compulsory but, in some cases, it can be waived with previous work experience if it is related to the content of the program. The main difference between vocational high school and vocational college is the explained requirements to access each level.

Vocational education is attained by around $20 \%$ of young people, as it is shown in Figure 2, where we present the distribution of the educational levels of people aged 20-29 years old over the period 2001-2007. As we can see, the evolution of the educational attainment of young people is quite stable over this period, in such way that the distributions of schooling levels are very similar 
in 2001 and 2007. On the other hand, we can observe that the educational levels are grouped into two categories. The first one comprises compulsory education, academic high school and university or more and it includes around 70\% of total people aged 20-29 years old. The other three schooling levels (primary or less, vocational high school and vocational college) form a second category that comprises the remaining $30 \%$ of people. Thus, the educational attainment of young people in Spain is mainly academic oriented.

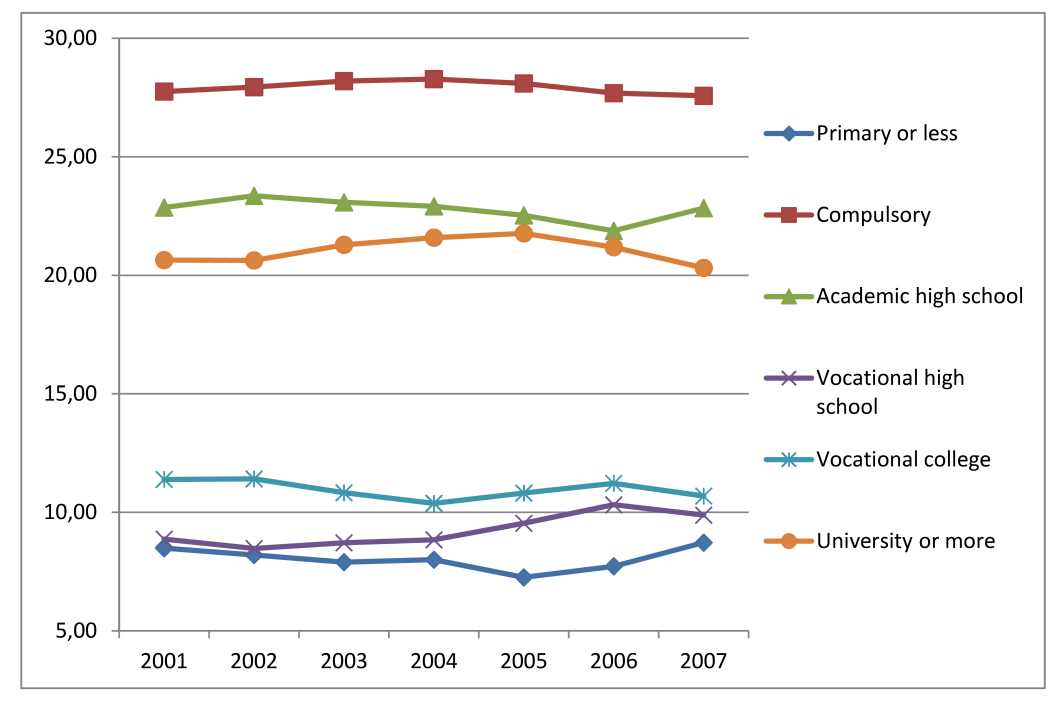

Figure 2: Schooling levels of people aged 20-29 years old (\%, Spanish Labour Force Survey)

\section{Dataset}

The data we use come from the Survey on Education and Labour Market Transitions, produced by the Spanish Statistics Institute in 2005. The objective of this survey is to know the education and labour decisions of individuals who completed any non-university education level in the school year 2000/2001. Specifically, the sampled groups are individuals who completed compulsory schooling, academic high school, vocational high school or vocational college in that school year. For the purpose of the paper we use the last two samples.

The survey collects information about education and labour activities since 2000/2001 until 2005 by using a retrospective interview. In consequence, individual decisions are observed along four years following graduation from vocational high school or vocational college. The dataset contains three types of information:

- Personal characteristics. Individuals report date of birth, gender, mother and father's education and province of residence.

- Education. Individuals indicate the age at which they finished the corresponding vocational schooling level, the program field completed and the type of school attended (private, semi- 
private $^{3}$ or public). As we explain above, vocational education includes apprenticeship in firms and the survey ask individuals whether this was their first work experience. In addition, the survey provides information on educational histories for the next years.

- Work. On a monthly basis, all individuals are asked about their employment or unemployment status. If they work, they report whether the job is part-time or full-time. Besides, a questionnaire on the job characteristics is asked to those individuals who are in some of the following situations:

1. They work in a full-time job at the moment of the interview.

2. They worked in a full-time job in the same firm for at least six consecutive months in the past.

Individuals have to fill in as many questionnaires as times they are in any of the previous situations. The questions about the job refer to the activity of the firm, occupation, net monthly wage on an interval basis, type of contract, hours worked, necessary qualification for the job, starting and finishing dates, the means that the individual used to find the job and the reason why she quit (only for past jobs).

The initial sample sizes are 7,615 and 11,244 individuals with vocational high school and vocational college, respectively ${ }^{4}$. As we are interested in comparing the school to work transitions of people who have attained vocational high school or vocational college as their maximum schooling level, we decide to focus on the subsample of individuals who do not attend further education in order to avoid misleading results. Thus, we drop 6,726 individuals who report to have attended any educational level between 2001 and 2005. Final sample sizes are 5,725 individuals with vocational high school and 6,408 with vocational college.

Table 1 contains a description of the two samples. As we can see, the proportion of females is a bit higher among those who completed vocational college. On the other hand, individuals who obtained a vocational high school diploma are younger. However, this is not surprising, given that vocational college is tertiary education, while vocational high school is secondary one (see Figure 1). More than $70 \%$ of individuals completed vocational education in a public school, while very few people attended a private one ${ }^{5}$.

With respect to parents' education, in general, a mother has a lower schooling attainment than a father. It is also interesting to note that the percentage of people who report not knowing parents' education is lower among those who completed vocational college.

\footnotetext{
${ }^{3}$ Semi-private refers to "colegio concertado".

${ }^{4}$ We drop 21 individuals who reported having completed vocational high school with less than seventeen years old or vocational college with less than eighteen years old. Because these situations are impossible according to the schooling system explained previously, we consider them as measurement errors.

${ }^{5}$ According to the Ministry of Education, in 2001, around $70 \%$ of the schools that offer vocational education are public.
} 
Regarding the apprenticeship, it is important to remind that it is compulsory and intended to give all individuals an initial job experience before entering the labour market. However, it can be waived with previous labour experience if it is related to the content of the vocational program. If previous jobs are not connected with that content, individuals need to take the apprenticeship. The information in the questionnaire allows us to distinguish among those situations. Thus, we construct the following three mutually exclusive variables:

- Apprenticeship (1 ${ }^{\text {st }}$ labour experience): equal to one if an individual took the apprenticeship and this was her first labour experience.

- Apprenticeship (previous labour experience): equal to one if an individual took the apprenticeship although she had worked previously.

- No apprenticeship: equal to one if an individual did not take the apprenticeship because it was waived with previous labour experiences.

Table 1 shows that few individuals did not complete the apprenticeship in vocational high school $(3 \%)$ while the percentage is higher in vocational college (12\%). We can see also that the proportion of individuals for whom the apprenticeship was her first labour experience is higher in vocational high school than in vocational college. However, the percentage of people who completed the apprenticeship having previous experience is similar (around 50\%).

Finally, with respect to the type of program field, those with vocational high school are more likely to finish a program in Clerical and Transportation or in Manufacturing, while around $40 \%$ of people with vocational college have completed a program in Social Services; few people obtained a degree in the field of Agriculture and Fishery.

According to Figure 1, a student who completes education on time is between 17 and 18 years old in vocational high school and between 19 and 20 years old in vocational college. We proxy performance with the age when students finished education because the survey does not provide information on grades. Regarding this, as we can see in Table 2, there are many individuals who finished vocational high school with more than 18 years old or who graduated from vocational college with more than 20. However, one possible concern in using the age as a proxy for performance is whether finishing older is consequence of bad results in vocational education or in previous attended schooling levels. Unfortunately, we cannot distinguish between these situations because the database does not have enough information. Nonetheless, we know from the sample of people who completed compulsory schooling in 2001, that most of those who attend vocational education did not finish previous schooling levels on time (see Section 6 for more discussion). They usually finished with one or two years of delay, so, completing vocational school on time implies that individuals will be around 19-20 and 21-22 years old in vocational high school or vocational college, respectively. As observed in Table 2, we do find that more than $50 \%$ of students have 
finished vocational education with those ages. This evidence suggests that the age when people completed vocational education can be used as a proxy for performance, although taking into consideration that the evidence is not conclusive.

\section{Duration analysis}

The database is very adequate to analyse differences in the transitions to labour market from the two vocational levels because we observe individuals in the beginning of their labour careers, just after completing vocational schooling. In addition, as the target population of the survey is people who completed education in 2001, all individuals, independently of the vocational level finished, face the same bussiness cycle conditions when they start to search for a job. We study these transitions across vocational schooling levels by comparing the duration, measured as number of months, until finding the first full-time job and the duration until finding the first "significant" fulltime job. We concentrate on full-time instead of part-time jobs because, in Spain, people mainly search for a full-time employment. According to Eurostat 2005, only around $13 \%$ of people work in a part-time employment. And, in our sample we observe very few individuals who do not find a full-time job (see Table 3). On the other hand, we define a job as significant if it lasted at least, six consecutive months. This definition is used by the Spanish Statistic Institute in different surveys (LFS, EU-SILC, Survey on Education and Labour Market Transitions) to collect information on job characteristics. We construct the duration variables by using the monthly-based information on individual employment status.

\subsection{A first look to the duration data}

In our sample, we observe that the percentage of individuals who do not find a job (significant or not) between 2001 and 2005 is very small (see Table 3). Not surprisingly, the percentage is a bit higher when we refer to find a significant job. We observe also some differences by gender: few men do not get any type of job while the percentages for women are higher, specially with respect to find a significant job. In addition, we are also interested in looking at the percentage of individuals for whom the first significant job is also the first job. We find that this proportion is around $71 \%$ in both types of vocational education. So, this is a first evidence on the success of transitions from school to work because most individuals find a job and, more important, for most of them the first job is significant. However, with respect to this, we do not find any important difference between vocational high school and vocational college.

In Table 4, we can see that most individuals find the first significant job in 2001 (that is, in the same year in which they finished their studies) or in the next year. So, at the end of 2002, around $90 \%$ of people had found a significant job. The pattern is very similar with respect to find a first job although with greater values by the end of 2002 (around 95\%). Here, we do observe differences 
across vocational levels. Among those individuals with vocational college, the percentage who find an employment in 2001 is higher for both types of job in comparison with the percentages in vocational high school.

Another important issue is to analyse whether there are differences in average duration to find a job by vocational study, apprenticeship and age when individuals finished education. On average, people with vocational high school or vocational college last around 3.8 months to find the first job and around 6.0 months to find a significant employment. However, distinguishing by the apprenticeship variables, these numbers hide important differences, as we can see in the first two rows of Panels A and B of Table 5. Individuals with apprenticeship and previous experience present the lowest average duration in finding both jobs. Interestingly, in Panel B, people who did not take the apprenticeship have the highest average in both types of vocational schooling. Surprisingly, we do not observe a clear decreasing or increasing age pattern in average duration in either vocational high school or vocational college. In consequence, it seems that completing vocational education on time does not provide any advantage to find a job. However, we have to be cautious on drawing this conclusion because we do not have information of the years previous to complete vocational education. For example, a student can finish school at an older age because she was working before attending education. In this case, this person can find a job more quickly than younger students just because she has networks or a better knowledge on job search methods due to her previous experience in the labour market. If this is true, maybe, the fact that we do not observe differences between younger and older students indicates that completing education on time does provide some type of advantage. Nonetheless, if finishing at older ages is only because these students performed badly during education, then, the lack of differences in average duration by age is evidence that good performance does not give any return.

Finally, and before turning to the estimation of the duration models, we have explored the patterns of getting a job by vocational education using the Kaplan-Meier estimates of the empirical hazard. They are shown in Figures 3 and 4 (first job and first significant job, respectively). Regarding the first significant job, the patterns are more or less the same between vocational high school and vocational college: the hazards fall very quickly from the first to the sixth month and, then, they fall slowly and monotonically. The same behaviour is observed in the duration to find the first job, although in this case, the hazards fall even more quickly in the first months.

\subsection{Duration models}

We analyse the determinants of the transitions from school to the first (significant or not) job by estimating a duration model. We use discrete-time models since, in our data, exit to employment occurs in continuous time although we only observe time at one-month intervals ${ }^{6}$. Let $T$ be a discrete duration random variable indicating number of months and taking on values $\{1,2,3, \ldots\}$

\footnotetext{
${ }^{6}$ See Lancaster (1990) and Jenkins $(1995,2005)$ for the basic features of such models.
} 


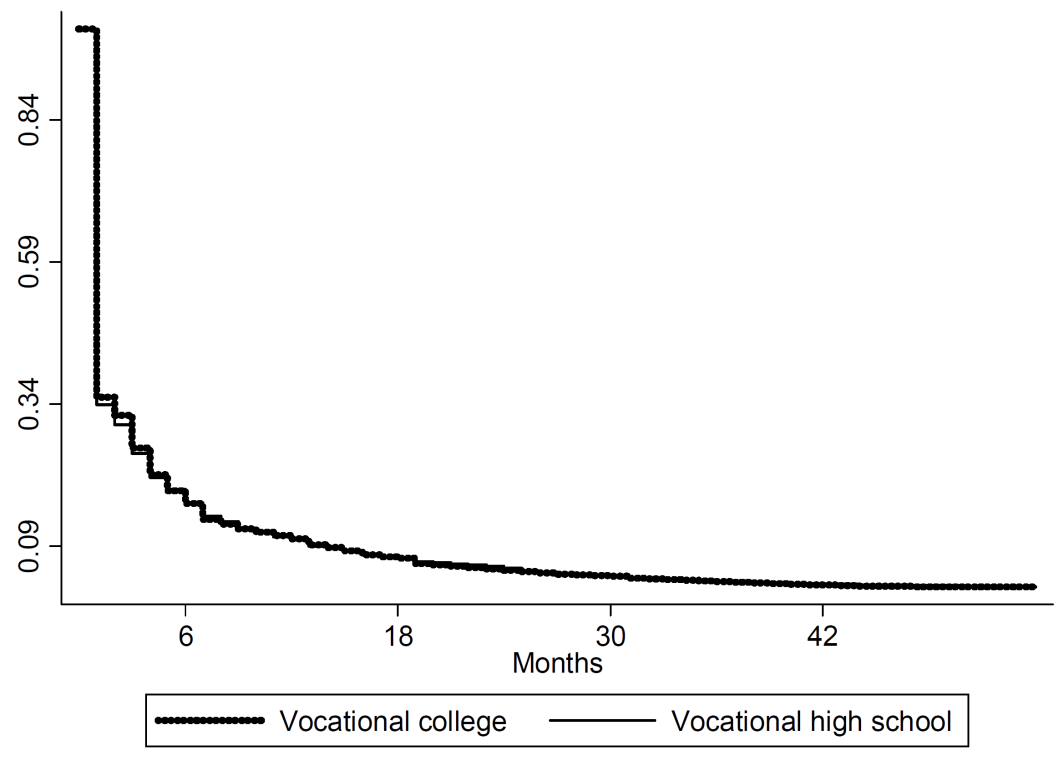

Figure 3: Kaplan-Meier empirical hazard to first job

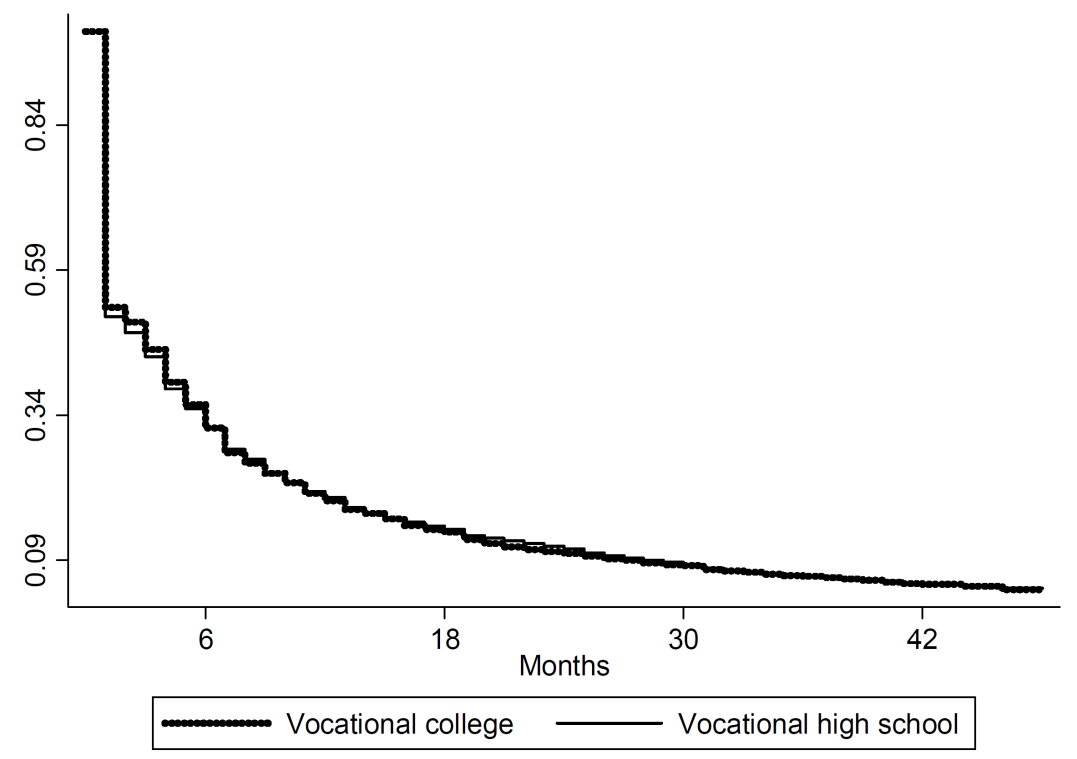

Figure 4: Kaplan-Meier empirical hazard to first significant job

with probability mass function:

$$
p(t)=\operatorname{Pr}(T=t), \quad t=1,2, \ldots
$$

and cumulative distribution function:

$$
F(t)=\operatorname{Pr}(T \leq t)=p(1)+p(2)+\ldots+p(t)
$$


The hazard function is

$$
\begin{aligned}
h(t) & =\operatorname{Pr}(T=t \mid T \geq t)=\frac{\operatorname{Pr}(T=t)}{\operatorname{Pr}(T \geq t)}=\frac{\operatorname{Pr}(T=t)}{1-\operatorname{Pr}(T \leq t-1)} \\
& =\frac{p(t)}{1-p(1)-\ldots-p(t-1)}=\frac{F(t)-F(t-1)}{1-F(t-1)} \text { for } t>1
\end{aligned}
$$

and $h(1)=p(1)=F(1)$. The hazard gives probabilities of exit to employment defined over the surviving population at each time. The hazard function conditional on covariates is given by $h(t, X)=\operatorname{Pr}(T=t \mid T \geq t, X)$. We consider a complementary log-log (cloglog) specification for the hazard rate:

$$
h(t, X)=1-\exp \left[-\exp \left(\beta^{\prime} X+c(t)\right)\right]
$$

The cloglog is a proportional hazard model, where $c(t)$ is the baseline hazard function which summarizes the pattern of duration dependence and it is not affected by individual covariates $X$. We assume that duration dependence is characterized by $c(t)=r \log t$. Thus, the hazard function is given by

$$
h(t, X)=1-\exp \left(-\lambda t^{r}\right), \quad \lambda=\exp \left(\beta^{\prime} X\right)
$$

As Jenkins (2005) points out, this is the discrete-time analogue to the continuous-time Weibull model. The parameter $r$ determines whether the hazard is increasing $(r>0)$, decreasing $(r<0)$, or constant over time $(r=0)$, similarly to the shape parameter in a Weibull model ${ }^{7}$. The cloglog model is adequate to our data because of the monotonic and decreasing hazard rates, as shown in Figures 3 and 4 .

One of the main issues concerning the estimation of hazard regressions is unobserved heterogeneity. Ignoring unobserved individual characteristics may bias the estimates of the effect of observed explanatory variables in the hazard function. To deal with this issue, we consider the presence of unobserved heterogeneity in the duration model by following the approach proposed by Heckman and Singer (1984). In particular, we assume that the unobserved heterogeneity follows a "mass point" distribution that takes on two different values $\left(\mu_{1}\right.$ and $\left.\mu_{2}\right)$ with probabilities $p_{1}$ and $p_{2}$ respectively. The estimates are obtained by maximizing a finite-mixture likelihood function where $\mu_{1}, \mu_{2}, p_{1}$ and $p_{2}$ are additional parameters to be estimated.

Finally, with respect to the covariates, we include the variables shown in Table 1: female, age when an individual finished education, type of vocational school (private, public or semi-private), educational attainment of both parents, type of program field and region dummies. We also include the three dummy variables that indicate whether an individual took the apprenticeship and whether this was her first labour experience: Apprenticeship (1 $1^{\text {st }}$ labour experience), Apprenticeship (previous labour experience) and No apprenticeship.

\footnotetext{
${ }^{7}$ In the Weibull specification, the hazard function is $h(t, X)=p \lambda t^{p-1}$, where $\lambda=\exp \left(\beta^{\prime} X\right)$ and $p$ is the shape parameter.
} 


\section{Results}

In this Section, we present the results on the determinants of the duration to find the first job and the first significant job for each type of vocational education. We show the estimates from three specification models (M1, M2 and M3) which consider different sets of explanatory variables. M1 includes female, age when an individual finished education, type of school and apprenticeship dummies. Specification M2 adds parents' education and M3 also controls for the type of program field ${ }^{8}$. We also present estimates after including individual unobserved heterogeneity in the specification with all the covariates. All Tables report the baseline hazard estimates associated with a change in the value of one of the covariates using the complementary-loglog model explained in previous Section. Hazard ratios have the virtue of being easy to interpret: those greater than one indicate that a one unit increase in the covariate rises the baseline hazard (lower expected duration), while those less than one indicate a decrease in the hazard to find a job (greater expected duration).

\subsection{First job}

Table 6 contains the hazard ratio estimates to find a first job corresponding to the three sets of explanatory variables. First of all, for each type of vocational education, we do not find important differences across specifications. The only exception is with respect to the public school dummy in vocational college which increases duration in all specifications although it is only significant in the last column at $10 \%$ level.

On the other hand, comparing the estimates of the third specification (M3) for vocational high school and vocational college (columns four and seven), we observe some similarities but also some important differences. We obtain that women are $20 \%$ more likely than men to experience a greater duration in unemployment and this effect does not differ by type of vocational education. The age when an individual finished education reduces the hazard in vocational high school while it decreases the duration in vocational college, and in both cases the effects are small but significant. As we comment in Section 3, this variable can be used as a proxy for performance. However, given the lack of information on previous paths, we also have to take into account that a higher age does not reflect necessarily bad results but simply later attendance. If finishing older is a consequence of bad performance, probably, the higher the age, the higher the duration in unemployment. On the contrary, if it is a consequence of starting later in education because that person was working previously, a higher age could reduce the duration. This can explain the different effects that we find across types of vocational education.

From a policy perspective, the most relevant covariates are the type of school and the apprenticeship dummies. We find that these variables have different effects on duration depending on the type of vocational education. Interestingly, attending a private school does not have significant

\footnotetext{
${ }^{8}$ All the specifications include region dummies. For brevity reasons, we do not show the results in the Tables although they are available upon request.
} 
effects on the duration to find a first job for those who completed vocational high school, whereas it increases duration for those with vocational college. On the other hand, individuals who have completed vocational high school in a public school have a lower duration in unemployment than those who attended a semi-private school. In vocational college, attending a public school increases the duration although the effect is only significant at $10 \%$ level.

Concerning the apprenticeship dummies, in vocational high school, we obtain that those students who took the apprenticeship are more likely to exit to employment. The effect is very significant and big, specially for the individuals who took the apprenticeship and had previous labour experience. This is evidence that, in vocational high school, apprenticeship is very important to improve the transition from school to work. In consequence, waiving apprenticeship with previous experienced does not seem an adequate policy. The fact that the covariate apprenticeship (previous labour experience) has higher effects than apprenticeship ( $1^{\text {st }}$ labour experience) indicates that previous labour market knowledge combined with apprenticeship is also very important. In vocational college, we observe different effects: Apprenticeship $\left(1^{\text {st }}\right.$ labour experience) reduces the hazard rate in a 9\%, while apprenticeship (previous labour experience) is not significant.So, it seems that apprenticeship is important in the upper secondary education but not in the tertiary one. Nevertheless, as we comment below, once we control for unobserved heterogeneity (Table 7), apprenticeship in vocational college has also positive effects on the probability of finding a job.

With respect to parents' education, we obtain that those individuals whose parents have upper secondary or tertiary education present lower hazard ratios than those whose parents' education is compulsory or less. In principle, this negative effect can seem surprising, but it can be driven by parents' preferences that favour academic high school and university instead of vocational education. According to these preferences many parents will try to convince their children to continue in education after completing vocational school instead of searching for a job. This will imply greater duration spells, specially if parents' educational attainment is high, and this could explain our results. Additionally, if parents' education proxies income, then individuals with low educated parents need to start to work as soon as possible to contribute to the household income. This also explains why people with high educated parents have lower hazard rates.

Finally, the type of program field also plays a role in finding a job. Specifically, in both vocational levels, completing a program in Manufacturing or Building has important effects in reducing the expected duration with respect to obtain a program in Agriculture and Fishery. The impact is around 55-57\% for Building and 22-25\% for Manufacturing. Clerical and Transportation also decreases duration although the effect is only significant in vocational high school. We do not find evidence that completing a program in Social Services affects the duration.

In Table 7, we present the results, once we control for unobserved heterogeneity, corresponding to the specification with all the covariates. Unobserved heterogeneity captures all factors, different from the observed ones, that affect duration. It is very plausible that there are individual char- 
acteristics, such as motivation or ability to find a job or to progress in education, that affect the length of spells but that we do not observe. Therefore, it is important to control for the presence of such factors in order to avoid biased estimates in the rest of covariates. Following Heckman and Singer (1984), we consider that there are two types of individuals regarding unobserved characteristics. The results show that type two individuals are more likely to spend less time searching for a job while those of type one have lower hazard ratios (see last rows of Table 7). Thus, individuals of type two have more motivation or ability to find a job. Its proportion in the population is similar in both levels of vocational education ( $61 \%$ and $59 \%$, respectively).

Regarding the estimates of the other covariates, we observe some important changes with respect to the estimates obtained without controlling for unobserved heterogeneity. Now, in vocational college, the age when an individual finished education does not reduce the hazard ratio, while in vocational high school, the effect is even greater. Thus, after including unobserved heterogeneity we obtain evidence that finishing older increases duration until finding a job. The positive effect of public school on the hazard ratio in vocational high school is robust to control for unobserved heterogeneity while the effect is not significant in vocational college. In the latter, the negative effect of attending a private school also disappears. With respect to the two apprenticeship dummies, in vocational high school, the sign is the same as in previous estimates but the magnitude of the effects is higher. On the other hand, unlike Table 6 , the apprenticeship (previous labour experience) dummy shows a positive and significant effect on the hazard ratio in vocational college. This reinforces the evidence that apprenticeship improves the transitions from school to work and that, from this perspective, waiving it with previous experiences does not seem an appropriate educational policy. The conclusions about the estimates of the parents' education covariates are similar to the ones shown in Table 6. Finally, with respect to the type of program field, only Building remains significant after controlling for unobserved heterogeneity. Its positive effect can be explained by the expansion of the construction sector in Spain between 2000 and 2007 due to the housing bubble.

Until now, our analysis is focused on all the individuals who find a first full-time job. However, there is around $2-3 \%$ of them who had a previous part-time employment. In consequence, these individuals can have formed networks in the labour market that help them to find a full-time job. Or, maybe, those individuals worked in a part-time employment because they have different unobserved characteristics. Thus, we explore whether our results can be driven by the presence of these individuals. Regarding this, we obtain new estimates after dropping individuals with a previous part-time job (Table 8) shows the results. In general, both in vocational high school and in vocational college, the estimates are very similar to those presented in Table 6 . We find only slight differences which are mainly referred to a lower significance of some estimates. In vocational high school, the age when an individual finished education, and the programs in Manufacturing or Clerical and Transportation have similar effects although they are not significant. In vocational 
college, the Manufacturing field has positive effects but, unlike Table 6, it is not significant. Additionally, the apprenticeship (previous labour experience) dummy has a similar effect on expected duration but, in this case, it is significant at $10 \%$ level.

\subsection{First significant job}

Table 9 contains the hazard ratio estimates to find a first significant job corresponding to the three sets of explanatory variables. Like in Table 6 , for each type of vocational education, there are not important differences across specifications. That is, the estimates of the covariates considered in the three specification models are robust to the inclusion of additional variables. Thus, we just comment the results on the specification with all the covariates (columns four and seven of Table 9). First of all, from a comparison across vocational levels in Tables 6 and 9, we can see that, in vocational high school, the covariates have similar effects (in terms of sign, magnitude and significance) on the duration spells to both types of jobs. However, we detect some differences. For instance, the effect of the apprenticeship dummies is also positive but smaller than in Table 6 and the effect corresponding to apprenticeship ( $1^{\text {st }}$ labour experience) is less significant. Additionally, the estimates of parents' education also present some differences: now, having a father with tertiary education or a mother with upper secondary education does not affect duration, while if an individual has a mother with tertiary schooling her hazard rate is $15 \%$ lower. The main differences in the determinants of duration to find each type of job are observed for individuals with vocational college. Unlike Table 6 , we do not obtain that older individuals have higher hazard ratios, and on the contrary, the age when an individual finished education does not have any significant effect. Although attending a private or a public school have also negative effects in the hazard ratio to a significant job, the significance levels are lower. On the other hand, now, apprenticeship has a positive effect on the hazard rate to a significant job at $1 \%$ level and higher for individuals who combined apprenticeship with previous labour experience. Again apprenticeship is an important factor to obtain a more stable job in both levels of vocational education. This result is robust to include unobserved heterogeneity in the estimation, as it is shown in Table 10. Finally, the only type of the program field in vocational college that increases the hazard to a significant job is Building.

In Table 10, we show the results, once we control for unobserved heterogeneity, corresponding to the specification with all the covariates. We also assume that there are two types of individuals in the population. Individuals of type two are around $40 \%$ and they are characterized by a higher ability or motivation to find a significant job. Nevertheless, the estimates are not significant. On the other hand, unobserved characteristics of type one individuals decrease the hazard ratio and they are significant at $1 \%$ level.

Regarding the other covariates, the main differences with respect to the estimates obtained without controlling for unobserved heterogeneity are referred to the type of school and the ap- 
prenticeship variables. Specifically, the negative effect of attending a private school in vocational college disappears and the effects of apprenticeship are greater in both types of vocational levels. Thus, like for the first job, we find strong evidence in favor of apprenticeship as a way of improving transitions from vocational school to a significant employment.

Like in previous Subsection, we complete our analysis by exploring to what extent the results can be influenced by individuals who had worked in a full-time or part-time job before finding a first significant job. These individuals can have different unobserved characteristics or they can have formed networks which make easier to find a significant job. As we comment in Section 4.1, the percentage of individuals for whom the first significant job is also the first job is $71 \%$. So, the remaining $29 \%$ are individuals who find a significant job after having worked in a full-time employment that lasted less than six months. In Table 11 we show the estimates after dropping those individuals. There are some differences with respect to the estimates of Table 9 but the main conclusions do hold. In vocational high school, the older an individual finished education, the lower is the hazard ratio, although, the effect is not significant. We continue finding evidence that apprenticeship is very important to obtain a significant job, but just for those individuals who had worked before attending vocational education. With respect to parents' education, the effects go in the same direction as previous estimates, although in Table 11 there are some differences in the significance of the effects. Finally, for the group of individuals who did not work since they finished education until finding a significant job, only holding a Building program increases the hazard rate significantly.

\section{Discussion}

In the previous analysis we have found relevant differences neither in duration nor in the estimates of the determinants of transitions across types of vocational education. We study the beginning of labour careers and this could explain the lack of differences. However, we have to take into account that, besides the number of months to find a job, there could exist differences in other dimensions (such as wage, occupation, contract,...). So, in this Section, we explore more deeply this possibility as the database has information on the characteristics of the first significant job ${ }^{9}$.

Table 12 shows some job characteristics disaggregated by vocational education and gender, and distinguishing also between self-employed and employee workers. We observe very few selfemployed individuals (around 4\%), with no differences by gender or level of education. Regarding the duration of the first significant job, we consider separately past and current jobs, which are significant jobs that expired or not, respectively, before the moment of the interview. As we can see, the duration for current jobs is higher (more than double) than for past jobs, although it does not differ importantly by vocational high school and college, gender and type of worker.

\footnotetext{
${ }^{9}$ Unfortunately, the dataset does not report information for all jobs that lasted less than six months.
} 
Looking at the required degree at the workplace, a high proportion of individuals answer that no specific level of education is required, and this share is lower in vocational college. Other $40-50 \%$ of workers respond that their level of education fit the required degree. In this case, we observe that for men, the percentages are higher in vocational college than in vocational high school while for women there are not differences across vocational schooling levels. This result is stressed when we check if the needed qualification at the workplace is below, equal or above their level of education: about 65\%-70\% of workers answer that is equal and other 20-30\% respond that the needed qualification is below (the last percentages are higher in vocational college, reflecting a proportion of overqualified people greater than in vocational high school). With respect to the method to find the significant job, most individuals use the networks (family, friends, worker colleagues) as the main channel. However, according to our previous results, apprenticeship plays an important role for searching a job, specially for employee.

The principal difference between the two types of vocational education can be found in the occupation: people with vocational high school work mainly in high blue-collar occupations while those with vocational college are employed mainly, and with similar percentages, in low white-collar and high blue-collar occupations. Finally, the main sectors where people work are manufacturingextraction, commerce and services but there are not great differences across types of vocational education, except for the services sector, where percentages are higher in vocational college. As expected, we find differences by gender, suggesting that there is some gender segregation by sector (in particular, for Construction and Education-Health).

In Table 13, we explore more in detail the characteristics of the first significant job for employees. In particular, we look at the type of contract and the monthly wage, by gender and type of vocational education ${ }^{10}$. In line with the Spanish labour market, we observe that many workers (around $42 \%$ ) have a temporary contract while very few (5\%) have a permanent one. Curiously, comparing across levels of education, people with more years of schooling (vocational college) present higher percentages of fixed-term contracts, although as we can see in the next rows, wages are higher ${ }^{11}$. We also find a gender wage gap in both types of education: in vocational high school (vocational college), around $50 \%(45 \%)$ of women earn below 750 euros while this percentage is about $32 \%$ (29\%) for men.

To sum up, few differences are detected in job characteristics by vocational level. Nevertheless, there is evidence that workers with vocational college are more employed in white collar occupations, with higher wages although with a high proportion of fixed-term contracts. It seems that, to some extent, the Spanish labour market recognizes that the two levels of vocational education provides different skills and this is reflected in the type of job found.

\footnotetext{
${ }^{10}$ As self-employed represent only $4 \%$ of workers, and to avoid misleading results regarding wages and type of contract, we exclude them from this Table.

${ }^{11}$ The survey provides information on wages in an interval basis.
} 
A complete understanding of the early labour market outcomes requires to explore the type of individual who attends each vocational education level and whether there are differences among them. As discuss in Lopez-Mayan (2010), following compulsory education, only around $15 \%$ of students choose vocational high school. Besides, this is a track mainly attended by people who completed compulsory schooling with delay $(33 \%$ and $43 \%$ for people with one and two years of delay, respectively, versus $7 \%$ for students who finished on time). On the other hand, vocational college is chosen by $19 \%$ of individuals who obtained an academic high school diploma ${ }^{12}$ and, again, this path is mainly attended by students who did not graduate on time $(41 \%$ and $14 \%$ with and without delay, respectively ${ }^{13}$ ). From this evidence, it seems that individuals enrolled in vocational college and vocational high school share similar characteristics because they attend vocational education after having experienced a delay in the previous schooling level completed.

\section{Conclusions}

In this work we analyse the determinants of the transitions from vocational education to work, focusing on whether starting with different levels of vocational education implies also differences in those transitions. In the Spanish system, young people can enter the labour market with vocational high school (upper secondary education) or with vocational college (tertiary education). Both types of vocational education include a period of workplace training, although, as they belong to different schooling levels, they have also different entry requirements: enrollment in vocational high school requires the compulsory schooling diploma while in vocational college the certificate corresponding to the general upper secondary track is needed. This implies that individuals with vocational college have more years of education than individuals with vocational high school and, so, we would expect that the latter had a less successful entry in the labour market.

For our purpose, we use a unique micro-dataset on schooling and labour histories elaborated by the Spanish Statistics Institute in 2005 (Survey on Education and Labour Market Transitions), which it is the only Spanish dataset with information of this type.

We study transitions by looking at the number of months to find a first job and a first "significant" job (defined as a job which lasts at least six consecutive months). We do not obtain important differences in the estimates of the determinants of duration between types of vocational levels. For instance, in both cases being a female, finishing vocational education older or having high educated parents reduce the exit to an employment. Our results also show that apprenticeship has a very important role on increasing the hazard rate to employment from the two types of vocational education. Moreover, this result holds after controlling for both unobserved heterogeneity and previous labour experience. Attending a public school has positive effects on the hazard,

\footnotetext{
${ }^{12}$ Most individuals with a vocational high school diploma decide to enter the labour market and not to continue in education (see Lopez-Mayan (2010))

${ }^{13}$ From a sample of 7750 individuals who completed compulsory education in 2001 (Survey on Education and Labour Market Transitions 2005).
} 
although only for individuals with vocational high school.

To complete the analysis, we have considered whether there exist differences across levels of vocational education in the characteristics of the job obtained. Regarding this, we only find that workers with vocational college are more employed in white collar occupations, with higher wages although with a great proportion of fixed-term contracts $^{14}$.

Our main contribution is to provide a better understanding on the labour market entry of students with vocational education in Spain. It seems that the Spanish labour market recognizes that the two levels of vocational education provides different skills. From a policy perspective, the results on the role of public schools and workplace training on smoothing this entry are very important, specially nowadays, when young people have difficulties to enter the labour market due to the recession. The fact that individuals who took the apprenticeship are more successful in finding a job highlights that the workplace training has to be considered as an important aspect of any educational reform. Related to this, waiving the apprenticeship with previous experience does not seem an adequate educational policy because individuals in that situation experience higher unemployment spells. Workplace training can aid the matching between employers and young people, making learning more applied and relevant.

\footnotetext{
${ }^{14}$ The differences in duration and in job characteristics by gender remain a challenge to be addressed in future research.
} 


\section{References}

Albert, C., L. Toharia, and M. A. Davia (2008): "To Find or Not To Find a First "Significant" Job," Revista de Economia Aplicada, 46, 37-59.

Bertschy, K., M. A. Cattaneo, and S. C. Wolter (2008): "What Happened to the PISA 2000 Participants Five Years Later?" IZA Discussion Paper No. 3323.

Blazquez-Cuesta, M. And J. I. Garcia-Perez (2007): "School to Work Transitions and the Impact of Public Expenditure on Education," Documento de Trabajo FEDEA No. 13.

Bover, O. And R. Gomez (2004): "Another Look at Unemployment Duration: Exit to a Permanent vs. a Temporary Job," Investigaciones Económicas, 28, 285-314.

Dolado, J. J., F. Felgueroso, and J. F. Jimeno (2000): "Youth labour markets in Spain: Education, training, and crowding-out," European Economic Review, 44, 943-956.

GregG, P. (2001): "The Impact of Youth Unemployment on Adult Unemployment in the NCDS," The Economic Journal, 111, F626-F653.

Heckman, J. J. And G. T. BorJas (1980): "Does Unemployment Cause Future Unemployment? Definitions, Questions and Answers from a Continuous Time Model of Heterogeneity and State Dependence," Economica, 47, 247-283.

Heckman, J. J. And B. Singer (1984): “A Method for Minimizing the Impact of Distributional Assumptions in Econometric Models for Duration Data," Econometrica, 52, 271-320.

Jenkins, S. P. (1995): "Easy Estimation Methods for Discrete-time Duration Models," Oxford Bulletin of Economics and Statistics, 57, 120-138.

— (2005): "Survival Analysis," Unpublished manuscript, Institute for Social and Economic Research, University of Essex.

Lancaster, T. (1990): The Econometric Analysis of Transition Data, Cambridge University Press.

Lopez-Mayan, C. (2010): "Demand for Post-compulsory Education: The Choice Between Academic and Vocational Tracks," Mimeo.

OECD (2000): "From Initial Education to Working Life. Making Transitions Work," OECD Publications.

PArey, M. (2009): "Vocational Schooling versus Apprenticeship Training-Evidence from Vacancy Data-," Working Paper. 
RYAn, P. (2001): "The School-to-Work Transition: A Cross-National Perspective," Journal of Economic Literature, 39, 34-92.

Stewart, M. B. (2007): "The Interrelated Dynamics of Unemployment and Low-wage Employment," Journal of Applied Econometrics, 22, 511-531. 
TABLES:

Table 1: Sample description

\begin{tabular}{|c|c|c|c|c|}
\hline & \multicolumn{2}{|c|}{ Vocational High School } & \multicolumn{2}{|c|}{ Vocational College } \\
\hline & Mean & Std. dev. & Mean & Std. dev. \\
\hline Female & 0.45 & 0.50 & 0.50 & 0.50 \\
\hline Age when finished education & 20.13 & 1.40 & 21.53 & 1.18 \\
\hline \multicolumn{5}{|l|}{ Type of school: } \\
\hline Public & 0.73 & 0.44 & 0.75 & 0.43 \\
\hline Semi-private & 0.25 & 0.43 & 0.19 & 0.39 \\
\hline Private & 0.02 & 0.13 & 0.06 & 0.23 \\
\hline \multicolumn{5}{|l|}{ Father's education: } \\
\hline Compulsory or less & 0.65 & 0.48 & 0.65 & 0.48 \\
\hline High school & 0.11 & 0.32 & 0.14 & 0.35 \\
\hline Tertiary & 0.07 & 0.26 & 0.11 & 0.31 \\
\hline Don’t know & 0.16 & 0.38 & 0.10 & 0.30 \\
\hline \multicolumn{5}{|l|}{ Mother's education: } \\
\hline Compulsory or less & 0.72 & 0.45 & 0.73 & 0.44 \\
\hline High school & 0.10 & 0.30 & 0.13 & 0.34 \\
\hline Tertiary & 0.04 & 0.19 & 0.06 & 0.23 \\
\hline Don’t know & 0.14 & 0.34 & 0.08 & 0.28 \\
\hline \multicolumn{5}{|l|}{ School-based apprenticeship: } \\
\hline Apprenticeship ( $1^{s t}$ labour experience) & 0.49 & 0.50 & 0.41 & 0.49 \\
\hline Apprenticeship (previous labour experience) & 0.48 & 0.50 & 0.47 & 0.50 \\
\hline No apprenticeship & 0.03 & 0.16 & 0.12 & 0.32 \\
\hline \multicolumn{5}{|l|}{ Program field: } \\
\hline Agriculture-Fishery & 0.03 & 0.16 & 0.01 & 0.12 \\
\hline Manufacturing & 0.31 & 0.46 & 0.23 & 0.42 \\
\hline Building & 0.05 & 0.22 & 0.06 & 0.24 \\
\hline Clerical and Transportation & 0.35 & 0.48 & 0.28 & 0.45 \\
\hline Social services & 0.27 & 0.44 & 0.41 & 0.49 \\
\hline \multicolumn{5}{|l|}{ Region: } \\
\hline Northwest & 0.08 & 0.27 & 0.10 & 0.29 \\
\hline Northeast & 0.12 & 0.32 & 0.14 & 0.35 \\
\hline East & 0.17 & 0.37 & 0.15 & 0.36 \\
\hline Centre & 0.47 & 0.50 & 0.47 & 0.50 \\
\hline South & 0.16 & 0.37 & 0.15 & 0.35 \\
\hline $\mathrm{N}$ & \multicolumn{2}{|r|}{ (5725 } & \multicolumn{2}{|r|}{6408} \\
\hline
\end{tabular}

Northwest: Galicia, Asturias, Cantabria. Northeast: Basque Country, La Rioja, Navarra, Aragon. East: Catalonia, Valencia, Balear Islands. Centre: Madrid, Extremadura, Castilla-Leon, Castilla-La Mancha. South: Andalusia, Canary Islands, Ceuta-Melilla, Murcia. 
Table 2: Percentage of students by age when finished education

\begin{tabular}{ccc}
\hline & Vocational High School & Vocational College \\
\hline \hline 17 & 0.94 & - \\
18 & 10.41 & 0.16 \\
19 & 24.21 & 4.00 \\
20 & 27.41 & 16.60 \\
21 & 19.32 & 26.86 \\
22 & 11.65 & 28.23 \\
23 & 5.80 & 23.28 \\
24 & 0.17 & 0.47 \\
25 & 0.09 & 0.41 \\
\hline \hline $\mathrm{N}$ & 5725 & 6408 \\
\hline
\end{tabular}

Table 3: Percentage of students who do not find a job

\begin{tabular}{lcccc}
\hline & \multicolumn{2}{c}{ Vocational High School } & \multicolumn{2}{c}{ Vocational College } \\
\hline \hline \multirow{2}{*}{ First job } & Women & Men & Women & Men \\
\cline { 2 - 5 } $\mathrm{N}$ & 3.02 & 1.31 & 2.57 & 1.16 \\
& 78 & 41 & 83 & 37 \\
First significant job & 7.31 & 3.37 & 6.32 & 3.43 \\
$\mathrm{~N}$ & 189 & 106 & 204 & 109 \\
\hline \hline
\end{tabular}

Table 4: Percentage of students by year when finding the job

\begin{tabular}{lcccc}
\hline & \multicolumn{2}{c}{ Vocational High School } & \multicolumn{2}{c}{ Vocational College } \\
\hline \hline & First job & First significant job & First job & First significant job \\
\cline { 2 - 5 } 2001 & 68.44 & 57.72 & 80.47 & 67.12 \\
2002 & 25.81 & 31.16 & 14.11 & 22.81 \\
2003 & 3.69 & 7.00 & 3.50 & 6.46 \\
2004 & 1.84 & 4.11 & 1.61 & 3.56 \\
2005 & 0.21 & 0.02 & 0.32 & 0.05 \\
Total & 100 & 100 & 100 & 100 \\
\hline \hline $\mathrm{N}$ & 5606 & 5430 & 6288 & 6095 \\
\hline
\end{tabular}


Table 5: Average number of months to find the job

A. First job

\begin{tabular}{cccccc}
\hline \hline \multicolumn{3}{c}{ Vocational High School } & \multicolumn{3}{c}{ Vocational College } \\
\hline App. $1^{\text {st }}$ & App. previous & No app. & App. $1^{\text {st }}$ & App. previous & No app. \\
\hline
\end{tabular}

Full sample*:

$\begin{array}{cccccc}4.54 & 2.93 & 4.99 & 4.56 & 3.23 & 3.77 \\ (7.28) & (5.47) & (8.09) & (7.37) & (5.80) & (6.52)\end{array}$

By age when finished education:

$\begin{array}{ccccccc}17 & 6.23 & 4.50 & 12.50 & - & - & - \\ 18 & 4.55 & 3.19 & 8.77 & 1.00 & 1.80 & 9.67 \\ 19 & 3.83 & 2.86 & 4.41 & 4.57 & 3.57 & 5.32 \\ 20 & 4.73 & 2.66 & 3.65 & 4.36 & 3.70 & 3.64 \\ 21 & 4.65 & 3.06 & 4.00 & 4.51 & 3.09 & 3.46 \\ 22 & 5.41 & 2.95 & 7.40 & 4.52 & 3.10 & 3.87 \\ 23 & 4.79 & 3.24 & 4.30 & 5.08 & 3.32 & 3.53 \\ 24 & 9.00 & 2.13 & - & 1.60 & 2.24 & 3.00 \\ 25 & 15.50 & 4.67 & - & 1.50 & 1.43 & 1.00 \\ & & & & & & 711\end{array}$

B. First significant job

\begin{tabular}{llllll}
\hline \hline \multicolumn{3}{c}{ Vocational High School } & \multicolumn{3}{c}{ Vocational College } \\
\hline App. $1^{\text {st }}$ & App. previous & No app. & App. $1^{\text {st }}$ & App. previous & No app. \\
\hline
\end{tabular}

Full sample*:
6.54
5.37
8.04
6.42
5.53
6.54
(8.77)
$(7.83)$
(10.51)
(8.48)
$(7.95)$
$(8.56)$

By age when finished education:

\begin{tabular}{ccccccc}
17 & 7.74 & 8.72 & 1.00 & - & - & - \\
18 & 6.09 & 5.04 & 9.23 & 1.00 & 4.00 & 11.50 \\
19 & 5.72 & 5.08 & 8.90 & 6.11 & 5.70 & 7.84 \\
20 & 7.06 & 4.90 & 7.78 & 6.06 & 5.69 & 5.86 \\
21 & 6.64 & 5.61 & 5.12 & 6.59 & 5.54 & 7.01 \\
22 & 7.05 & 5.82 & 13.71 & 6.28 & 5.58 & 7.26 \\
23 & 8.12 & 6.46 & 4.89 & 6.97 & 5.46 & 4.93 \\
24 & 9.00 & 3.00 & - & 4.10 & 5.06 & 3.00 \\
25 & 15.50 & 4.67 & - & 3.25 & 2.08 & 9.25 \\
& & & & & & \\
\hline $\mathrm{N}$ & 2633 & 2668 & 129 & 2494 & 2919 & 682 \\
\hline \hline
\end{tabular}

*Standard deviation in parenthesis.

App. $1^{s t}$ : Apprenticeship ( $1^{s t}$ labour experience).

App. previous: Apprenticeship (previous labour experience).

No app.: No apprenticeship. 
Table 6: Hazard ratio estimates (First job)

\begin{tabular}{|c|c|c|c|c|c|c|}
\hline & \multicolumn{3}{|c|}{ Vocational High School } & \multicolumn{3}{|c|}{ Vocational College } \\
\hline & M1 & M2 & M3 & M1 & M2 & M3 \\
\hline Female & $\begin{array}{r}0.78^{* * *} \\
(0.02)\end{array}$ & $\begin{array}{r}0.77^{* * *} \\
(0.02)\end{array}$ & $\begin{array}{r}0.80^{* * *} \\
(0.02)\end{array}$ & $\begin{array}{r}0.79^{* * * *} \\
(0.02)\end{array}$ & $\begin{array}{r}0.77^{* * * *} \\
(0.02)\end{array}$ & $\begin{array}{r}0.80^{* * *} \\
(0.02)\end{array}$ \\
\hline Age when finished education & $\begin{array}{r}0.97^{* * *} \\
(0.01)\end{array}$ & $\begin{array}{r}0.97^{* * * *} \\
(0.01)\end{array}$ & $\begin{array}{r}0.97^{* * * *} \\
(0.01)\end{array}$ & $\begin{array}{r}1.03^{* * * *} \\
(0.01)\end{array}$ & $\begin{array}{r}1.03 * * * \\
(0.01)\end{array}$ & $\begin{array}{r}1.03^{* * *} \\
(0.01)\end{array}$ \\
\hline Duration dependence $(\log t)$ & $\begin{array}{r}0.43^{* * *} \\
(0.01)\end{array}$ & $\begin{array}{r}0.43^{* * *} \\
(0.01)\end{array}$ & $\begin{array}{r}0.43^{* * *} \\
(0.01)\end{array}$ & $\begin{array}{r}0.44^{* * * *} \\
(0.01)\end{array}$ & $\begin{array}{r}0.44^{* * * *} \\
(0.01)\end{array}$ & $\begin{array}{r}0.45^{* * *} \\
(0.01)\end{array}$ \\
\hline \multicolumn{7}{|c|}{ Type of school (ref.: Semi-private): } \\
\hline Private school & $\begin{array}{r}0.86 \\
(0.09)\end{array}$ & $\begin{array}{r}0.87 \\
(0.09)\end{array}$ & $\begin{array}{r}0.91 \\
(0.10)\end{array}$ & $\begin{array}{r}0.79^{* * *} \\
(0.05)\end{array}$ & $\begin{array}{r}0.82^{* * *} \\
(0.05)\end{array}$ & $\begin{array}{r}0.87^{* *} \\
(0.05)\end{array}$ \\
\hline Public school & $\begin{array}{r}1.11^{* * *} \\
(0.03)\end{array}$ & $\begin{array}{r}1.10^{* * * *} \\
(0.03)\end{array}$ & $\begin{array}{r}1.11^{* * *} \\
(0.03)\end{array}$ & $\begin{array}{r}0.95 \\
(0.03)\end{array}$ & $\begin{array}{r}0.95 \\
(0.03)\end{array}$ & $\begin{array}{c}0.94^{*} \\
(0.03)\end{array}$ \\
\hline \multicolumn{7}{|c|}{ Apprenticeship (ref.: No apprenticeship): } \\
\hline $1^{\text {st }}$ labour experience & $\begin{array}{r}1.31^{* * *} \\
(0.12)\end{array}$ & $\begin{array}{r}1.28^{* * *} \\
(0.11)\end{array}$ & $\begin{array}{r}1.28^{* * *} \\
(0.11)\end{array}$ & $\begin{array}{r}0.89 * * * \\
(0.04)\end{array}$ & $\begin{array}{r}0.89^{* * *} \\
(0.04)\end{array}$ & $\begin{array}{r}0.91^{* *} \\
(0.04)\end{array}$ \\
\hline Previous labour experience & $\begin{array}{r}1.69^{* * *} \\
(0.15)\end{array}$ & $\begin{array}{r}1.65^{* * *} \\
(0.15)\end{array}$ & $\begin{array}{r}1.65^{* * *} \\
(0.15)\end{array}$ & $\begin{array}{r}1.02 \\
(0.04)\end{array}$ & $\begin{array}{r}1.02 \\
(0.04)\end{array}$ & $\begin{array}{r}1.05 \\
(0.04)\end{array}$ \\
\hline \multicolumn{7}{|c|}{ Parents' education (ref.: Compulsory or less): } \\
\hline Upper secondary (father) & & $\begin{array}{r}0.97 \\
(0.04)\end{array}$ & $\begin{array}{r}0.97 \\
(0.04)\end{array}$ & & $\begin{array}{r}0.97 \\
(0.04)\end{array}$ & $\begin{array}{r}0.98 \\
(0.04)\end{array}$ \\
\hline Tertiary (father) & & $\begin{array}{r}0.83^{* * *} \\
(0.05)\end{array}$ & $\begin{array}{r}0.84^{* * * *} \\
(0.05)\end{array}$ & & $\begin{array}{r}0.85^{* * * *} \\
(0.04)\end{array}$ & $\begin{array}{r}0.85^{* * *} \\
(0.04)\end{array}$ \\
\hline "Don’t know" (father) & & $\begin{array}{r}0.82^{* * * *} \\
(0.05)\end{array}$ & $\begin{array}{r}0.82^{* * *} \\
(0.05)\end{array}$ & & $\begin{array}{r}1.01 \\
(0.07)\end{array}$ & $\begin{array}{r}1.00 \\
(0.07)\end{array}$ \\
\hline Upper secondary (mother) & & $\begin{array}{r}0.87^{* * *} \\
(0.04)\end{array}$ & $\begin{array}{r}0.87^{* * *} \\
(0.04)\end{array}$ & & $\begin{array}{r}1.05 \\
(0.04)\end{array}$ & $\begin{array}{r}1.05 \\
(0.04)\end{array}$ \\
\hline Tertiary (mother) & & $\begin{array}{r}0.89 \\
(0.07)\end{array}$ & $\begin{array}{r}0.89 \\
(0.07)\end{array}$ & & $\begin{array}{c}0.90^{*} \\
(0.05)\end{array}$ & $\begin{array}{c}0.91^{*} \\
(0.05)\end{array}$ \\
\hline "Don't know" (mother) & & $\begin{array}{l}1.13^{*} \\
(0.08)\end{array}$ & $\begin{array}{l}1.13^{*} \\
(0.08)\end{array}$ & & $\begin{array}{r}0.92 \\
(0.07)\end{array}$ & $\begin{array}{r}0.92 \\
(0.07)\end{array}$ \\
\hline Program field (ref.: Agricultu & e-Fishery & & & & & \\
\hline Manufacturing & & & $\begin{array}{r}1.22^{* *} \\
(0.11)\end{array}$ & & & $\begin{array}{r}1.25^{* *} \\
(0.13)\end{array}$ \\
\hline Building & & & $\begin{array}{r}1.55^{\text {*** }} \\
(0.16)\end{array}$ & & & $\begin{array}{r}1.57^{* * *} \\
(0.18)\end{array}$ \\
\hline Clerical and Transportation & & & $\begin{array}{r}1.25^{* *} \\
(0.11)\end{array}$ & & & $\begin{array}{r}1.17 \\
(0.12)\end{array}$ \\
\hline Social services & & & $\begin{array}{r}1.10 \\
(0.10)\end{array}$ & & & $\begin{array}{r}1.05 \\
(0.11)\end{array}$ \\
\hline Constant & $\begin{array}{r}1.09 \\
(0.24) \\
\end{array}$ & $\begin{array}{r}1.08 \\
(0.24) \\
\end{array}$ & $\begin{array}{r}0.85 \\
(0.20) \\
\end{array}$ & $\begin{array}{r}0.47^{* * *} \\
(0.11) \\
\end{array}$ & $\begin{array}{r}0.44^{* * *} \\
(0.10) \\
\end{array}$ & $\begin{array}{r}0.38^{* * * *} \\
(0.10) \\
\end{array}$ \\
\hline Regions & Yes & Yes & Yes & Yes & Yes & Yes \\
\hline Log-likelihood & -11626.8 & -11604.1 & -11557.0 & -13326.9 & -13311.7 & -13280.8 \\
\hline Observations & 27258 & 27258 & 27258 & 30591 & 30591 & 30591 \\
\hline $\mathbf{N}$ & 5606 & 5606 & 5606 & 6288 & 6288 & 6288 \\
\hline
\end{tabular}

Dependent variable: number of months to find the first job after completing vocational education. Significance levels: $* * * 1 \% ; * * 5 \% ; * 10 \%$. Standard errors in parenthesis. 
Table 7: Hazard ratio estimates with unobserved heterogeneity (First job)

\begin{tabular}{|c|c|c|}
\hline \multirow{2}{*}{$\overline{\text { Female }}$} & Vocational High School & \multirow{2}{*}{$\begin{array}{r}\text { Vocational College } \\
0.80^{* * *}\end{array}$} \\
\hline & $\begin{array}{r}0.74^{* * *} \\
(0.04)\end{array}$ & \\
\hline Age when finished education & $\begin{array}{r}0.94^{* * *} \\
(0.01)\end{array}$ & $\begin{array}{r}0.99 \\
(0.02)\end{array}$ \\
\hline Duration dependence $(\log t)$ & $\begin{array}{r}0.78^{* * *} \\
(0.02)\end{array}$ & $\begin{array}{r}0.80^{* * *} \\
(0.02)\end{array}$ \\
\hline \multicolumn{3}{|c|}{ Type of school (ref.: Semi-private): } \\
\hline Private school & $\begin{array}{r}0.84 \\
(0.13)\end{array}$ & $\begin{array}{r}0.90 \\
(0.08)\end{array}$ \\
\hline Public school & $\begin{array}{r}1.13^{* *} \\
(0.06)\end{array}$ & $\begin{array}{r}1.00 \\
(0.05)\end{array}$ \\
\hline \multicolumn{3}{|c|}{ Apprenticeship (ref.: No apprenticeship): } \\
\hline $1^{\text {st }}$ labour experience & $\begin{array}{r}1.37^{*} \\
(0.22)\end{array}$ & $\begin{array}{r}1.01 \\
(0.07)\end{array}$ \\
\hline Previous labour experience & $\begin{array}{r}2.07^{* * * *} \\
(0.34)\end{array}$ & $\begin{array}{r}1.20^{* * *} \\
(0.08)\end{array}$ \\
\hline \multicolumn{3}{|c|}{ Parents' education (ref.: Compulsory or less): } \\
\hline Upper secondary (father) & $\begin{array}{r}1.00 \\
(0.07)\end{array}$ & $\begin{array}{r}0.91 \\
(0.07)\end{array}$ \\
\hline Tertiary (father) & $\begin{array}{r}0.95 \\
(0.09)\end{array}$ & $\begin{array}{r}0.79^{* * * *} \\
(0.06)\end{array}$ \\
\hline "Don't know" (father) & $\begin{array}{r}0.75^{* * *} \\
(0.07)\end{array}$ & $\begin{array}{r}0.88 \\
(0.10)\end{array}$ \\
\hline Upper secondary (mother) & $\begin{array}{r}0.81^{* * *} \\
(0.06)\end{array}$ & $\begin{array}{r}1.13 \\
(0.09)\end{array}$ \\
\hline Tertiary (mother) & $\begin{array}{r}0.87 \\
(0.11)\end{array}$ & $\begin{array}{r}0.93 \\
(0.08)\end{array}$ \\
\hline "Don’t know" (mother) & $\begin{array}{r}1.25^{* *} \\
(0.12)\end{array}$ & $\begin{array}{r}1.00 \\
(0.12)\end{array}$ \\
\hline \multicolumn{3}{|c|}{ Program field (ref.: Agriculture-Fishery): } \\
\hline Manufacturing & $\begin{array}{r}0.99 \\
(0.13)\end{array}$ & $\begin{array}{r}1.09 \\
(0.19)\end{array}$ \\
\hline Building & $\begin{array}{r}1.44^{* *} \\
(0.24)\end{array}$ & $\begin{array}{r}1.82^{* * *} \\
(0.35)\end{array}$ \\
\hline Clerical and Transportation & $\begin{array}{r}1.03 \\
(0.14)\end{array}$ & $\begin{array}{r}1.00 \\
(0.17)\end{array}$ \\
\hline Social services & $\begin{array}{r}0.94 \\
(0.13)\end{array}$ & $\begin{array}{r}0.90 \\
(0.15)\end{array}$ \\
\hline Unobserved heterogeneity: & & \\
\hline Constant type 1 & $\begin{array}{r}0.33^{* * *} \\
(0.13)\end{array}$ & $\begin{array}{r}0.17^{* * *} \\
(0.07)\end{array}$ \\
\hline Constant type 2 & $\begin{array}{r}7.74^{* * * *} \\
(2.96)\end{array}$ & $\begin{array}{r}4.58^{* * * *} \\
(2.03)\end{array}$ \\
\hline Probability type 2 & 0.61 & 0.59 \\
\hline Regions & Yes & Yes \\
\hline Log-likelihood & -10118.8 & -11540.4 \\
\hline$\overline{\text { Observations }}$ & 27258 & 30591 \\
\hline $\mathbf{N}$ & 5606 & 6288 \\
\hline
\end{tabular}

Dependent variable: number of months to find the first job after completing vocational education. Significance levels: $* * * 1 \% ; * * 5 \% ; * 10 \%$. Standard errors in parenthesis. 
Table 8: Hazard ratio estimates (First job without previous experience) Vocational High School Vocational College

\begin{tabular}{|c|c|c|}
\hline Female & $\begin{array}{r}0.84^{* * *} \\
(0.03)\end{array}$ & $\begin{array}{r}0.83^{* * *} \\
(0.02)\end{array}$ \\
\hline Age when finished education & $\begin{array}{r}0.99 \\
(0.01)\end{array}$ & $\begin{array}{r}1.04^{* * *} \\
(0.01)\end{array}$ \\
\hline Duration dependence $(\log t)$ & $\begin{array}{r}0.44^{* * *} \\
(0.01)\end{array}$ & $\begin{array}{r}0.45^{* * *} \\
(0.01)\end{array}$ \\
\hline \multicolumn{3}{|c|}{ Type of school (ref.: Semi-private): } \\
\hline Private school & $\begin{array}{r}0.94 \\
(0.10)\end{array}$ & $\begin{array}{r}0.75^{* * *} \\
(0.05)\end{array}$ \\
\hline Public school & $\begin{array}{r}1.11^{* * *} \\
(0.03)\end{array}$ & $\begin{array}{r}0.92^{* * *} \\
(0.03)\end{array}$ \\
\hline \multicolumn{3}{|c|}{ Apprenticeship (ref.: No apprenticeship): } \\
\hline $1^{\text {st }}$ labour experience & $\begin{array}{r}1.22^{* *} \\
(0.11)\end{array}$ & $\begin{array}{r}0.89^{* * * *} \\
(0.04)\end{array}$ \\
\hline Previous labour experience & $\begin{array}{r}1.62^{* * *} \\
(0.15)\end{array}$ & $\begin{array}{l}1.08^{*} \\
(0.05)\end{array}$ \\
\hline
\end{tabular}

Parents' education (ref.: Compulsory or less):

Upper secondary (father)

$0.99-1.04$

$(0.04)$

$(0.04)$

Tertiary (father)

$0.82^{* * *}$

$0.79^{* * *}$

$(0.05) \quad(0.04)$

"Don't know" (father)

$0.79^{* * *}$

0.96

$(0.05)$

$(0.07)$

Upper secondary (mother)

$0.90^{* *}$

(0.04)

(0.04)

Tertiary (mother)

0.89

0.98

(0.07)

(0.06)

"Don't know" (mother)

$1.14^{*}$

0.98

(0.08)

(0.08)

Program field (ref.: Agriculture-Fishery):

Manufacturing

1.11

1.07

(0.10)

Building

(0.12)

$1.45^{* * *}$

(0.15)

$1.35^{* * *}$

1.14

(0.16)

1.03

(0.10)

(0.11)

1.05

1.00

(0.09)

(0.11)

0.71

$0.40^{* * *}$

Constant

(0.17)

$(0.10)$

\begin{tabular}{lrr}
\hline Regions & Yes & Yes \\
\hline Log-likelihood & -10865.1 & -12132.3 \\
\hline \hline Observations & $\mathbf{2 4 0 4 0}$ & $\mathbf{2 6 2 0 9}$ \\
N & $\mathbf{5 4 7 0}$ & $\mathbf{6 1 1 1}$ \\
\hline
\end{tabular}

Dependent variable: number of months to find the first job after completing vocational education. Subsample of individuals without previous part-time labour experience. Significance levels: *** $1 \% ; * * 5 \% ; * 10 \%$. Standard errors in parenthesis. 
Table 9: Hazard ratio estimates (First significant job)

\begin{tabular}{|c|c|c|c|c|c|c|}
\hline & \multicolumn{3}{|c|}{ Vocational High School } & \multicolumn{3}{|c|}{ Vocational College } \\
\hline & M1 & $\mathrm{M} 2$ & M3 & M1 & M2 & M3 \\
\hline Female & $\begin{array}{r}0.77^{* * *} \\
(0.02)\end{array}$ & $\begin{array}{r}0.76^{* * *} \\
(0.02)\end{array}$ & $\begin{array}{r}0.79^{* * *} \\
(0.03)\end{array}$ & $\begin{array}{r}0.79^{* * *} \\
(0.02)\end{array}$ & $\begin{array}{r}0.78^{* * *} \\
(0.02)\end{array}$ & $\begin{array}{r}0.81^{* * *} \\
(0.02)\end{array}$ \\
\hline Age when finished education & $\begin{array}{r}0.97^{* * *} \\
(0.01)\end{array}$ & $\begin{array}{r}0.97^{* *} \\
(0.01)\end{array}$ & $\begin{array}{r}0.98^{* *} \\
(0.01)\end{array}$ & $\begin{array}{r}1.01 \\
(0.01)\end{array}$ & $\begin{array}{r}1.01 \\
(0.01)\end{array}$ & $\begin{array}{r}1.01 \\
(0.01)\end{array}$ \\
\hline Duration dependence $(\log t)$ & $\begin{array}{r}0.43^{* * *} \\
(0.01)\end{array}$ & $\begin{array}{r}0.43^{* * *} \\
(0.01)\end{array}$ & $\begin{array}{r}0.43^{* * *} \\
(0.01)\end{array}$ & $\begin{array}{r}0.44^{* * *} \\
(0.01)\end{array}$ & $\begin{array}{r}0.44^{* * *} \\
(0.01)\end{array}$ & $\begin{array}{r}0.45^{* * *} \\
(0.01)\end{array}$ \\
\hline \multicolumn{7}{|c|}{ Type of school (ref.: Semi-private): } \\
\hline Private school & $\begin{array}{r}0.88 \\
(0.10)\end{array}$ & $\begin{array}{r}0.89 \\
(0.10)\end{array}$ & $\begin{array}{r}0.92 \\
(0.11)\end{array}$ & $\begin{array}{r}0.80^{\text {*** }} \\
(0.05)\end{array}$ & $\begin{array}{r}0.83^{* * *} \\
(0.05)\end{array}$ & $\begin{array}{c}0.90^{*} \\
(0.06)\end{array}$ \\
\hline Public school & $\begin{array}{r}1.10^{* * *} \\
(0.03)\end{array}$ & $\begin{array}{r}1.09^{* * *} \\
(0.03)\end{array}$ & $\begin{array}{r}1.10^{* * * *} \\
(0.04)\end{array}$ & $\begin{array}{r}1.00 \\
(0.03)\end{array}$ & $\begin{array}{r}0.99 \\
(0.03)\end{array}$ & $\begin{array}{r}0.99 \\
(0.03)\end{array}$ \\
\hline \multicolumn{7}{|c|}{ Apprenticeship (ref.: No apprenticeship): } \\
\hline $1^{\text {st }}$ labour experience & $\begin{array}{c}1.19^{*} \\
(0.11)\end{array}$ & $\begin{array}{c}1.17^{*} \\
(0.11)\end{array}$ & $\begin{array}{c}1.17^{*} \\
(0.11)\end{array}$ & $\begin{array}{c}1.09^{*} \\
(0.05)\end{array}$ & $\begin{array}{c}1.09^{*} \\
(0.05)\end{array}$ & $\begin{array}{r}1.12^{* * *} \\
(0.05)\end{array}$ \\
\hline Previous labour experience & $\begin{array}{r}1.41^{* * *} \\
(0.13)\end{array}$ & $\begin{array}{r}1.40^{* * *} \\
(0.13)\end{array}$ & $\begin{array}{r}1.40^{* * *} \\
(0.13)\end{array}$ & $\begin{array}{r}1.16^{* * *} \\
(0.05)\end{array}$ & $\begin{array}{r}1.17^{* * *} \\
(0.05)\end{array}$ & $\begin{array}{r}1.21^{* * *} \\
(0.05)\end{array}$ \\
\hline \multicolumn{7}{|c|}{ Parents' education (ref.: Compulsory or less): } \\
\hline Upper secondary (father) & & $\begin{array}{r}0.94 \\
(0.04)\end{array}$ & $\begin{array}{r}0.95 \\
(0.04)\end{array}$ & & $\begin{array}{r}0.99 \\
(0.04)\end{array}$ & $\begin{array}{r}0.99 \\
(0.04)\end{array}$ \\
\hline Tertiary (father) & & $\begin{array}{r}0.94 \\
(0.06)\end{array}$ & $\begin{array}{r}0.94 \\
(0.06)\end{array}$ & & $\begin{array}{r}0.88^{* * *} \\
(0.04)\end{array}$ & $\begin{array}{r}0.88^{* * *} \\
(0.04)\end{array}$ \\
\hline "Don't know" (father) & & $\begin{array}{r}0.85^{* *} \\
(0.06)\end{array}$ & $\begin{array}{r}0.85^{* *} \\
(0.06)\end{array}$ & & $\begin{array}{r}1.01 \\
(0.07)\end{array}$ & $\begin{array}{r}1.01 \\
(0.07)\end{array}$ \\
\hline Upper secondary (mother) & & $\begin{array}{r}0.98 \\
(0.05)\end{array}$ & $\begin{array}{r}0.99 \\
(0.05)\end{array}$ & & $\begin{array}{r}1.01 \\
(0.04)\end{array}$ & $\begin{array}{r}1.01 \\
(0.04)\end{array}$ \\
\hline Tertiary (mother) & & $\begin{array}{r}0.84^{* *} \\
(0.07)\end{array}$ & $\begin{array}{r}0.85^{* *} \\
(0.07)\end{array}$ & & $\begin{array}{c}0.89^{*} \\
(0.06)\end{array}$ & $\begin{array}{c}0.90^{*} \\
(0.06)\end{array}$ \\
\hline "Don't know" (mother) & & $\begin{array}{r}1.09 \\
(0.08)\end{array}$ & $\begin{array}{r}1.09 \\
(0.08)\end{array}$ & & $\begin{array}{r}0.93 \\
(0.07)\end{array}$ & $\begin{array}{r}0.94 \\
(0.07)\end{array}$ \\
\hline Program field (ref.: Agricultu & e-Fishery) & & & & & \\
\hline Manufacturing & & & $\begin{array}{r}1.22^{* *} \\
(0.11)\end{array}$ & & & $\begin{array}{r}1.15 \\
(0.13)\end{array}$ \\
\hline Building & & & $\begin{array}{r}1.51^{* * *} \\
(0.16)\end{array}$ & & & $\begin{array}{r}1.44^{* * *} \\
(0.17)\end{array}$ \\
\hline Clerical and Transportation & & & $\begin{array}{r}1.24^{* *} \\
(0.11)\end{array}$ & & & $\begin{array}{r}1.09 \\
(0.12)\end{array}$ \\
\hline Social services & & & $\begin{array}{r}1.13 \\
(0.10)\end{array}$ & & & $\begin{array}{r}0.96 \\
(0.11)\end{array}$ \\
\hline Constant & $\begin{array}{r}0.64^{* *} \\
(0.15) \\
\end{array}$ & $\begin{array}{c}0.65^{*} \\
(0.15) \\
\end{array}$ & $\begin{array}{r}0.51^{* * *} \\
(0.13) \\
\end{array}$ & $\begin{array}{r}0.33^{* * *} \\
(0.08) \\
\end{array}$ & $\begin{array}{r}0.32^{* * *} \\
(0.08) \\
\end{array}$ & $\begin{array}{r}0.29^{* * * *} \\
(0.08) \\
\end{array}$ \\
\hline Regions & Yes & Yes & Yes & Yes & Yes & Yes \\
\hline Log-likelihood & -13923.6 & -13914.6 & -13902.8 & -15819.1 & -15808.9 & -15778.6 \\
\hline Observations & 44732 & 44732 & 44732 & 449923 & 449923 & 49923 \\
\hline $\mathbf{N}$ & 5430 & 5430 & 5430 & 6095 & 6095 & 6095 \\
\hline
\end{tabular}

Dependent variable: number of months to find the first significant job after completing vocational education. Significance levels: $* * * 1 \% ; * * 5 \% ; * 10 \%$. Standard errors in parenthesis. 
Table 10: Hazard ratio estimates with unobserved heterogeneity (First significant job)

\begin{tabular}{|c|c|c|}
\hline & Vocational High School & Vocational College \\
\hline Female & $\begin{array}{r}0.75^{* * *} \\
(0.03)\end{array}$ & $\begin{array}{r}0.84^{* * *} \\
(0.03)\end{array}$ \\
\hline Age when finished education & $\begin{array}{r}0.96^{* * *} \\
(0.01)\end{array}$ & $\begin{array}{r}1.00 \\
(0.02)\end{array}$ \\
\hline Duration dependence $(\log t)$ & $\begin{array}{r}0.76^{* * *} \\
(0.02)\end{array}$ & $\begin{array}{r}0.75^{* * *} \\
(0.02)\end{array}$ \\
\hline \multicolumn{3}{|c|}{ Type of school (ref.: Semi-private): } \\
\hline Private school & $\begin{array}{r}0.78 \\
(0.13)\end{array}$ & $\begin{array}{r}0.87 \\
(0.08)\end{array}$ \\
\hline Public school & $\begin{array}{r}1.10^{* *} \\
(0.05)\end{array}$ & $\begin{array}{r}0.99 \\
(0.05)\end{array}$ \\
\hline \multicolumn{3}{|c|}{ Apprenticeship (ref.: No apprenticeship): } \\
\hline $1^{\text {st }}$ labour experience & $\begin{array}{l}1.24^{*} \\
(0.15)\end{array}$ & $\begin{array}{r}1.15^{* *} \\
(0.07)\end{array}$ \\
\hline Previous labour experience & $\begin{array}{r}1.52^{* * *} \\
(0.19)\end{array}$ & $\begin{array}{r}1.25^{* * *} \\
(0.07)\end{array}$ \\
\hline \multicolumn{3}{|c|}{ Parents' education (ref.: Compulsory or less): } \\
\hline Upper secondary (father) & $\begin{array}{r}1.07 \\
(0.07)\end{array}$ & $\begin{array}{r}0.98 \\
(0.05)\end{array}$ \\
\hline Tertiary (father) & $\begin{array}{r}0.94 \\
(0.08)\end{array}$ & $\begin{array}{r}0.86^{* *} \\
(0.06)\end{array}$ \\
\hline "Don’t know" (father) & $\begin{array}{r}0.86^{*} \\
(0.08)\end{array}$ & $\begin{array}{r}1.04 \\
(0.10)\end{array}$ \\
\hline Upper secondary (mother) & $\begin{array}{r}0.93 \\
(0.07)\end{array}$ & $\begin{array}{r}1.04 \\
(0.06)\end{array}$ \\
\hline Tertiary (mother) & $\begin{array}{c}0.84^{*} \\
(0.09)\end{array}$ & $\begin{array}{r}0.89 \\
(0.08)\end{array}$ \\
\hline "Don't know" (mother) & $\begin{array}{r}1.11 \\
(0.11)\end{array}$ & $\begin{array}{r}0.99 \\
(0.10)\end{array}$ \\
\hline Program field (ref.: Agricultu & e-Fishery): & \\
\hline Manufacturing & $\begin{array}{r}1.22^{*} \\
(0.15)\end{array}$ & $\begin{array}{r}1.13 \\
(0.17)\end{array}$ \\
\hline Building & $\begin{array}{r}1.62^{* * *} \\
(0.24)\end{array}$ & $\begin{array}{r}1.44^{* *} \\
(0.24)\end{array}$ \\
\hline Clerical and Transportation & $\begin{array}{l}1.24^{*} \\
(0.15)\end{array}$ & $\begin{array}{r}1.06 \\
(0.16)\end{array}$ \\
\hline Social services & $\begin{array}{r}1.17 \\
(0.14)\end{array}$ & $\begin{array}{r}0.92 \\
(0.14)\end{array}$ \\
\hline Unobserved heterogeneity: & & \\
\hline Constant type 1 & $\begin{array}{r}0.18^{* * *} \\
(0.06)\end{array}$ & $\begin{array}{r}0.10^{* * *} \\
(0.04)\end{array}$ \\
\hline Constant type 2 & $\begin{array}{r}23.12 \\
(78.07)\end{array}$ & $\begin{array}{r}12.32 \\
(51.95)\end{array}$ \\
\hline Probability type 2 & 0.41 & 0.39 \\
\hline Regions & Yes & Yes \\
\hline Log-likelihood & -13402.2 & -15283.8 \\
\hline $\begin{array}{l}\text { Observations } \\
\mathrm{N}\end{array}$ & $\begin{array}{r}44732 \\
5430\end{array}$ & $\begin{array}{r}49923 \\
6095\end{array}$ \\
\hline
\end{tabular}

Dependent variable: number of months to find the first significant job after completing vocational education. Significance levels: ${ }^{* * *} 1 \%$; ** $5 \%$; $* 10 \%$. Standard errors in parenthesis. 
Table 11: Hazard ratio estimates (First significant job without previous experience) Vocational High School Vocational College

\begin{tabular}{lrr}
\hline \hline Female & $0.81^{* * *}$ & $0.80^{* * *}$ \\
& $(0.03)$ & $(0.03)$ \\
Age when finished education & 0.99 & 1.01 \\
& $(0.01)$ & $(0.01)$ \\
Duration dependence $(\log t)$ & $0.32^{* * *}$ & $0.34^{* * *}$ \\
& $(0.01)$ & $(0.01)$ \\
Type of school (ref.: Semi-private): & 0.93 & $0.79^{* * *}$ \\
Private school & $(0.13)$ & $(0.06)$ \\
& $1.11^{* * *}$ & 0.97 \\
Public school & $(0.04)$ & $(0.04)$ \\
& & 0.95 \\
Apprenticeship (ref.: No apprenticeship): & 1.01 & $(0.05)$ \\
$1^{\text {st }}$ labour experience & $(0.11)$ & $1.13^{* *}$ \\
& $1.39^{* * *}$ & $(0.06)$ \\
Previous labour experience & $(0.16)$ & \\
\end{tabular}

Parents' education (ref.: Compulsory or less):

Upper secondary (father)

$\begin{array}{rr}0.90^{*} & 0.99 \\ (0.05) & (0.05) \\ 0.84^{* *} & 0.86^{* *} \\ (0.06) & (0.05) \\ 0.78^{* * *} & 0.96 \\ (0.06) & (0.09) \\ 0.96 & 0.99 \\ (0.06) & (0.05) \\ 0.91 & 0.92 \\ (0.09) & (0.07) \\ 1.17^{*} & 0.93 \\ (0.10) & (0.10)\end{array}$

Program field (ref.: Agriculture-Fishery):

Tertiary (father)

"Don't know" (father)

$1.13 \quad 1.06$

Manufacturing

Building

Clerical support and transportation

Social services

Constant

\begin{tabular}{lrr}
\hline Regions & Yes & Yes \\
\hline Log-likelihood & -6012.9 & -6887.5 \\
\hline \hline Observations & $\mathbf{1 5 7 4 2}$ & $\mathbf{1 6 8 0 3}$ \\
N & $\mathbf{3 8 7 4}$ & $\mathbf{4 3 1 8}$ \\
\hline
\end{tabular}

Dependent variable: number of months to find the first significant job after completing vocational education. Subsample of individuals without previous (part-time or full-time) labour experience. Significance levels: *** $1 \% ; * * 5 \% ; * 10 \%$. Standard errors in parenthesis. 
Table 12: Characteristics of first significant job (\%, all workers)

\begin{tabular}{|c|c|c|c|c|c|c|c|c|}
\hline & \multicolumn{4}{|c|}{ Vocational high school } & \multicolumn{4}{|c|}{ Vocational college } \\
\hline & \multicolumn{2}{|c|}{ Women } & \multicolumn{2}{|c|}{ Men } & \multicolumn{2}{|c|}{ Women } & \multicolumn{2}{|c|}{ Men } \\
\hline & Self-employed & Employee & Self-employed & Employee & Self-employed & Employee & Self-employed & Employee \\
\hline Percentage & 3.63 & 96.37 & 5.83 & 94.17 & 3.70 & 96.30 & 4.27 & 95.73 \\
\hline \multicolumn{9}{|l|}{ Duration (in months) } \\
\hline \multicolumn{9}{|l|}{ Past jobs: } \\
\hline Average & 18.72 & 17.23 & 18.06 & 18.23 & 15.37 & 17.13 & 21.53 & 18.02 \\
\hline Standard dev. & 9.70 & 9.89 & 10.40 & 10.39 & 8.58 & 10.11 & 11.01 & 10.23 \\
\hline \multicolumn{9}{|l|}{ Current jobs*: } \\
\hline Average & 37.69 & 38.78 & 42.91 & 41.85 & 42.97 & 40.65 & 42.48 & 42.46 \\
\hline Standard dev. & 11.63 & 10.67 & 9.50 & 9.42 & 7.25 & 10.34 & 9.95 & 8.96 \\
\hline \multicolumn{9}{|l|}{ Required degree: } \\
\hline Compulsory & 1.15 & 7.06 & 2.82 & 5.42 & 4.46 & 4.09 & 3.82 & 3.20 \\
\hline Academic high school & 0.00 & 0.65 & 0.00 & 0.38 & 2.68 & 2.57 & 0.00 & 1.22 \\
\hline Vocational high school & 39.08 & 47.62 & 25.99 & 49.27 & 7.14 & 10.13 & 6.87 & 8.30 \\
\hline Vocational college & 4.60 & 2.47 & 2.26 & 3.60 & 36.61 & 47.34 & 33.59 & 55.67 \\
\hline University & 1.15 & 2.69 & 2.26 & 2.27 & 0.00 & 1.68 & 0.76 & 1.77 \\
\hline Not required & 44.83 & 37.87 & 59.89 & 37.44 & 41.96 & 32.23 & 48.09 & 27.73 \\
\hline Don’t know & 9.20 & 1.65 & 6.78 & 1.61 & 7.14 & 1.96 & 6.87 & 2.11 \\
\hline \multicolumn{9}{|l|}{ Needed qualification: } \\
\hline Below & 24.14 & 30.55 & 21.47 & 24.6 & 32.14 & 34.64 & 18.32 & 27.87 \\
\hline Equal & 66.67 & 65.25 & 66.67 & 70.05 & 62.5 & 62.48 & 73.28 & 68.49 \\
\hline Above & 9.20 & 4.20 & 11.86 & 5.35 & 5.36 & 2.88 & 8.40 & 3.64 \\
\hline \multicolumn{9}{|l|}{ Method to find the job: } \\
\hline Apprenticeship firm & 8.05 & 24.35 & 14.12 & 31.42 & 16.96 & 23.55 & 9.16 & 31.92 \\
\hline Networks & 41.39 & 64.83 & 42.93 & 57.58 & 50.89 & 62.8 & 36.63 & 54.17 \\
\hline Other & 50.56 & 10.82 & 42.95 & 10.98 & 32.15 & 13.65 & 54.21 & 13.91 \\
\hline \multicolumn{9}{|l|}{ Occupation $^{\dagger}:$} \\
\hline High white-collar & 13.79 & 0.65 & 9.6 & 0.59 & 9.82 & 1.75 & 9.92 & 3.30 \\
\hline Low white-collar & 18.39 & 37.65 & 8.47 & 14.00 & 49.11 & 65.05 & 30.53 & 42.5 \\
\hline High blue-collar & 54.02 & 54.77 & 72.88 & 69.00 & 38.39 & 28.94 & 48.85 & 43.59 \\
\hline Low blue-collar & 13.79 & 6.93 & 9.04 & 16.31 & 2.68 & 4.26 & 10.69 & 10.62 \\
\hline \multicolumn{9}{|l|}{ Sector: } \\
\hline Agriculture-Fishery & 4.60 & 0.78 & 14.69 & 2.52 & 0.89 & 0.51 & 10.69 & 1.46 \\
\hline Manufacturing-Extraction & 17.24 & 11.92 & 24.29 & 33.00 & 16.96 & 15.17 & 29.77 & 30.55 \\
\hline Construction & 3.45 & 2.43 & 20.34 & 21.00 & 4.46 & 3.67 & 13.74 & 12.59 \\
\hline Commerce & 26.44 & 28.16 & 19.77 & 21.00 & 22.32 & 21.66 & 16.03 & 14.87 \\
\hline Hotel industry & 6.90 & 7.80 & 11.86 & 5.88 & 8.93 & 5.73 & 6.11 & 3.91 \\
\hline Services & 12.64 & 17.59 & 3.95 & 11.93 & 25.00 & 28.90 & 16.03 & 28.79 \\
\hline Education-Health & 8.05 & 17.07 & 1.69 & 2.00 & 10.71 & 14.83 & 0.76 & 2.62 \\
\hline Other & 20.69 & 14.25 & 3.39 & 1.85 & 10.71 & 9.51 & 6.87 & 5.21 \\
\hline $\mathrm{N}$ & 87 & 2308 & 177 & 2858 & 112 & 2913 & 131 & 2939 \\
\hline
\end{tabular}

not expired at the moment of the interview. ${ }^{\dagger}$ High white-collar: Managers and Professionals. Low white-collar: Technicians and associate professionals; Clerical support workers. High blue-collar: Service and sale workers; Skilled agricultural; Craft and related trade workers; Plant and machine operators. Low blue-collar: No qualified occupations. 
Table 13: Characteristics of first significant job (\%, employee workers)

\begin{tabular}{|c|c|c|c|c|}
\hline & \multicolumn{2}{|c|}{ Vocational high school } & \multicolumn{2}{|c|}{ Vocational college } \\
\hline & Women & Men & Women & Men \\
\hline Type of Contract: & & & & \\
\hline Permanent & 6.46 & 5.28 & 4.98 & 4.15 \\
\hline Fixed-term & 39.3 & 42.72 & 42.54 & 47.19 \\
\hline No contract & 3.38 & 1.51 & 2.75 & 1.60 \\
\hline Other & 29.85 & 29.64 & 28.18 & 27.22 \\
\hline Don’t know & 21.01 & 20.85 & 21.55 & 19.84 \\
\hline Monthly wage*: & & & & \\
\hline$<433.55$ & 10.05 & 3.04 & 7.55 & 2.89 \\
\hline 433.55 to 750 & 40.08 & 28.90 & 36.94 & 26.10 \\
\hline 750 to 1000 & 9.88 & 23.97 & 13.53 & 25.76 \\
\hline 1000 to 1250 & 1.43 & 5.56 & 2.03 & 7.83 \\
\hline$>1250$ & 0.30 & 1.37 & 0.21 & 1.62 \\
\hline Don't know & 38.26 & 37.16 & 39.74 & 35.80 \\
\hline $\mathrm{N}$ & 2308 & 2858 & 2913 & 2939 \\
\hline
\end{tabular}

